\title{
Framework for Improving the Design and Configuration Process of Global Operations
}

\author{
S. Martínez ${ }^{1}$, A. Errasti ${ }^{1}$, J. Santos ${ }^{1}$, and M. Mediavilla ${ }^{2}$ \\ ${ }^{1}$ Engineering School, Tecnun, University of Navarra, San Sebastián, Spain \\ \{smartinez, aerrasti, jsantos\} @ tecnun.es \\ ${ }^{2}$ BSH Bosch und Siemens Hausgeräte GmbH, Munich, Germany \\ Miguel.Mediavilla@bshg.com
}

\begin{abstract}
In the current dynamic, volatile and competitive playground, the design and managing of global production and logistic networks has become a crucial issue even for SMEs, although with the difficult added that they have limited resources. Thus, how dealing with these complex production networks present a real challenge for this kind of companies. In order to do so, it is necessary to provide business managers a useful guideline to face the internationalization process in an effective way. Therefore, the aim of this paper is to propose a framework, which takes into account the three main problems (new facilities implementation, global supplier network and multi-site network) related to Operations configuration, to aid managers in the different stages of the decision making and propose useful principles, methods and techniques depending on the problem.
\end{abstract}

Keywords: Internationalization, SMEs, SBUs, Operations Strategy.

\section{Introduction}

Internationalization of production and logistics networks is a phenomenon that has gained momentum over the last decade as a consequence of the evolution of the competitive environment. Many manufacturing companies, in fact, have increased their international presence to remain competitive.

The internationalization of operations can take different forms and includes the development of new configurations such as international distribution systems, networks of global suppliers, and multi-site and/or fragmented manufacturing networks.

However, the starting up and supplier development process are some of the most difficult decisions to make, because it implies a lot of risks not only for multinational companies, but also and especially for SMEs (Small Medium Enterprises) and SBUs (Strategic Business Units) from Industrial Divisions, which resources are limited.

Many SMEs and SBUs of industrial divisions with local success fall down in foreign markets. Although, these are immersed in the globalization process, many of them are in the initial phase of internationalization in emerging market economies as well as in countries in transition, and need to be prepared for the challenges of new market economies [1]. 
Due to the rapid changes that have occurred during the last decades, almost every company or enterprise is affected by at least some kind of international challenge. Nevertheless, in the case of SMEs they have to cope with more difficulties because of having limited resources, limited market knowledge, limited use of networks and limited international experience of the entrepreneurs [2], and the same complications can affect to SBUs too. Consequently, the SMEs and SBUs internationalization process merits great attention.

Therefore, facing the management of a production logistic network in different countries is an enormous challenge which requires a greater coordination to get optimal levels of quality, flexibility and cost [3]. Summarizing, whilst all type of organisations are facing significant challenges for managing increasingly complex global operation, current literature on global operation networks is still limited in its scope [4-5]. Even more if it is considered SMEs and SBUs.

This paper shows the new improved version of the GlobOpe (Global Operations) Framework, which was exposed in the last APMS Conference, held in Stavanger (Norway) [6].

\section{Research Problems and Gap}

\subsection{New Production Facility Implementation}

The implementation of a production plant is the strongest step of any organization that seeks to internationalize [7], and for that besides the obvious economic investment, the establishment and subsequent management of the production facilities require a broad range of knowledge and skills related to operations management such as: establish agreements with local logistics suppliers, manage the expatriate staff, modify products and services to suit local requirements, etc.

On the other hand, some companies try to minimize the problems associated with the establishment through the acquisition of existing resources. In these cases, there might be a number of contingences, for example: the integration into the operating practices of the organization, incompatibility of the acquired information systems, etc.

\subsection{Supply Network Design and Sourcing}

Purchasing has evolved in the past few decades from a passive administrative role into a strategic function that contributes to creating a competitive advantage as much as other business functions [8]. This development is logical, given that purchases represent a large percentage of the final cost of the product and are of crucial importance for its quality and performance.

Hence, considering the definition of global or international purchasing given by [9] as "the activity for searching and obtaining goods, services and other resources on a possible worldwide scale, to comply with the needs of the company and with a view 
to continuing and enhancing the current competitive position of the company. The global purchasing includes all phases of the purchasing process, from before the definition of the specification list, through supplier selection and buying to the followup and evaluation phase. Furthermore, the global purchasing management is one of the first steps to define and design a global supply chain development [10].

Errasti [11] in his book about purchasing management identifies and explains in depth which are the challenges, risks and characteristics of the new purchasing function, some of them are: define the strategy in the supplier market, search for new suppliers, collect suppliers' value-added proposals and develop appropriate suppliers, integrate marketing and supply strategies in shorter product life cycles, define the contract management in the contract life cycle, negotiation power, face the different supply chain configurations, etc. For instance, in terms of supply chain configurations, it can be seen that nowadays in a multisite and fragmented production system, where the supplier network is composed of local or domestic suppliers and offshore suppliers and manufacturing facilities, these offshore suppliers and facilities need the coordination of quality control and the supply network with different delivery times and procurement reliability [12].

\subsection{Research Gap}

Although, there are many researchers about Global Operations, practical experiences have shown that strategy-specific checklists are needed, which might raise awareness of the real success factors of the pursued goal and avoid unpleasant surprises [13]. Moreover, different researchers [14-15] state the need to build models or frameworks of international manufacturing systems that help managers to design and manage their networks, which should take into account the requirements for the next generation of factories such as agility, flexibility, modularity, adaptability, etc. [16].

Hence, the examination of the literature revealed that there is a lack of methods and techniques to accomplish the design and configuration process of a global production and logistic network.

\section{Research Methodology}

There are many researchers who view the use of a mixture of methods as desirable, particularly in terms of developing valuable theory form observation and empirical analysis [17-18]. The important point is to choose the most appropriate methods for the investigation of the defined research question [19]. Then, a combination of different research methodologies have been chosen with the objective of reinforcing the week points of one method with the strengths of others. With these aims in mind and due to lack of space, the next table just mentions which have been the steps given by the researchers: 
Table 1. Roadmap of research methodology to build, test and verify the GlobOpe Framework

\begin{tabular}{|c|c|c|}
\hline$\underline{\text { Stage }}$ & Research Technique & Purpose or scope \\
\hline 1 & Literature review & Identify the gaps \\
\hline 2 & Constructive research [20] & $\begin{array}{l}\text { Develop the GlobOpe Model for New Facilities Imple- } \\
\text { mentation (NFI) }\end{array}$ \\
\hline \multirow[t]{2}{*}{3} & \multirow{2}{*}{$\begin{array}{l}\text { Action research (in a wind turbine } \\
\text { manufacturer) [21-22] }\end{array}$} & Test and verify the GlobOpe Model for NFI \\
\hline & & First thoughts about the necessity to expand the model \\
\hline \multirow[t]{2}{*}{4} & Literature review & Develop and improve the GlobOpe Model for Global \\
\hline & Case study [23] & Supplier Network Configuration (GSNC) \\
\hline 5 & $\begin{array}{l}\text { Action research (in two textile } \\
\text { industries) }\end{array}$ & Test the GlobOpe Model for GSNC \\
\hline 6 & $\begin{array}{l}\text { Multiple case studies and triangu- } \\
\text { lation }\end{array}$ & Verify and refine both models \\
\hline
\end{tabular}

\section{Theory Building: GlobOpe Framework}

\subsection{Scope}

The Framework called GlobOpe bears in mind the Operations Strategy key decisions that need to be made regarding a global production and logistic network configuration and design in the internationalization process. These key decisions are the following five: supply sources location (own and not own); strategic role; make or buy decisions; service delivery strategy and global operations network.

\subsection{Approach}

The methodology aids to determinate the problems specifications with the users help and it allows homogenizing the whole information. There are many modeling techniques, each one with special characteristics. According to the methodologies classification [24-25], the GlobOpe Framework covers the strategic and tactical horizon, the physic and decisional model nature and also the analysis, design and implementation stages.

\subsection{GlobOpe Framework}

The framework is centred in the most advanced stage of a company in terms of becoming global. According to the volume of international sales and the international production, the companies can be classified as: global, local, offshorer and exporter companies [26]. Nevertheless, companies are not tied to one of these strategies during their whole life cycle. Thus, they could change and adapt them. There are different behaviors and paths can be followed to achieve a rating of global competitor, but the GlobOpe Framework is focused on helping companies in the internationalization process, that is to say, to move from exporter to global. 
Hence, the goal of the GlobOpe Framework is the design and configuration process of a global production and logistic network, which can be a useful management tool for SMEs and SBUs steering committees responsible for the Global Operations effectiveness and efficiency [27].

The framework intends to fill the gap left by the other ones which are really useful in a stable environment but they are not suitable in a market dynamic environment [28] where new facilities implementation [13, 16, 29] supplier network development $[10,30,31]$ and multi-site network $[14,32]$ are needed.

Keeping in mind the GlobOpe presented in the previous APMS Conference [6] and after different project and researcher carried out, the researchers realize that the GlobOpe Framework needs to be enlarged. Therefore, the new GlobOpe Framework considers that there are three main problems related to Operations configuration in which the above decisions should be reviewed: new facilities implementation, global supplier network configuration and multi-site network configuration, so for each of them the researchers have developed a specific model. However, in this paper are only briefly exposed the first two pillars of the Framework.

\section{GlobOpe Model for New Facilities Implementation}

When assessing production locations abroad, companies tend to underestimate the necessary ramp up times [13] for securing process reliability, quality and productivity. Nevertheless, in order to manage such a ramp up with a high degree of precision, first a planning period phase is necessary, starting with the design of the product, the process and the supply chain network [33].

Therefore, the main goal to be achieved with this model is to manage the ramp up process with a high degree of precision and reduce ramp up delays in time and volume. With this aim in mind, when designing the model, the researchers have taken into consideration the following assumptions:

- Business Strategy should be aligned with Operations Strategy [34].

- A close coordination between agents in the supply chain due to the multiple possible configurations [12].

- Apply concurrent engineering: a planning period phase is necessary, starting with the design of the product, the process and the supply chain network in a parallel way [35].

- The physical and productive design should be adaptive.

- The process and management system have to be adapted to local characteristics [36].

- The shop floor management process has to be progressive [37] (start up, team and equipment stability, improvement and excellence).

- Think about the productive process strategy (fragmented or not). In case to be fragmented a decoupling point [38] could be needed to assure it.

- Supplier network design and configuration is the bottleneck in the ramp up process. 
Ultimately, bearing in mind the life cycle of a company, this model shows which are the analysis, operational, stability, improvement and excellence decisions that should be made and propose useful principles, methods and techniques in order to accomplished these decisions in an effective and efficient way.

\section{GlobOpe Model for Global Supplier Network Development}

There are companies, which have expanded their operations throughout the world. The purchasing is one of them, however, global purchasing can be the result of a reactive, opportunist decision to decrease the purchasing cost of one item, but it can also be a strategic and coordinated effort to pro-actively enhance the competitive position of the company. Consequently, in this case, the main goal to be reached with this model is to develop and design an accurate and reliable supply network. So that, when designing the model, the researchers have been aware of the following assumptions:

- The starting point is the suppliers' network design, which is considered as the bottleneck in the ramp up process.

- The global purchasing management is one of the first steps to define and design a global supply chain development [10].

- The global sourcing strategy has to be aligned with organizational design [39].

- Keeping in mind the five purchasing stages propose by Trent and Monczka [30] the researches define and summarize them in three stages, the first one is when company only purchase in domestic or local markets, the second is when the companies engage a close international purchasing strategy and the last one is when they develop a worldwide purchasing strategy.

In short, this model proposes purchasing policies or principles, levers or methods and techniques (for each stage) for aiding the decision process and identifying which are the next steps that the company needs to go through the next stage in the purchasing internationalization process.

\section{Contribution}

The framework developed is theoretically grounded and combines practical relevance and practical utility with theoretical novelty, all being criteria for evaluating the quality of constructive research [40].

For this reason, the GlobOpe Framework might be a practical guideline to help managers in the decision making in order to define the efficient and effective roadmap for their company depending on the problem that they have to face. On the one hand, the GlobOpe Model for New Facilities Implementation along with the principles and tools proposed could aid to increase effectiveness and decrease ramp up delays. It also allows managing the design and configuring the facilities supply network with a high degree of precision. On the other hand, the GlobOpe Model for Global Suppliers Network Configuration could be used as an assessment tool for a Steering Committee to help them in the global supplier development. 


\section{References}

1. Szabó, G.G.: New institutional economics and agricultural co-operatives: a Hungarian case study. In: Karafolas, S., Spear, R., Stryjan, Y. (eds.) Local Society \& Global Economy: The Role of Co-operatives. Naoussa: Editions Hellin, ICA International Research Conference, pp. 357-378 (2002)

2. Kalinic, I., Forza, C.: Rapid internationalization of traditional SMEs: Between gradualist models and born globals. International Business Review (2011)

3. De Meyer, A., Nakane, J., Miller, J., Ferdows, K.: Flexibility: the next competitive battle the manufacturing futures survey. Strategic Management Journal 10, 135-144 (1989)

4. Corti, D., Egaña, M.M., Errasti, A.: Challenges for off-shored operations: findings from a comparative multi-case study analysis of Italian and Spanish companies. In: Proceedings 16th Annual EurOMA Conference, Gothenburg (2009)

5. Laiho, A., Blomqvist, M.: International Manufacturing Networks: a literature review. In: Proceedings 17th Conference EurOMA, Porto (2010)

6. Martinez, S., Errasti, A.: Framework for International Manufacturing Network Design and Configuration: An Empirical Study in the Wind Sector. In: APMS Conference, Stavanger (2011)

7. Barnes, D.: The complexities of the manufacturing strategy formation process in practice. International Journal of Operations \& Production Management 22(10), 1090-1111 (2002)

8. Alinaghian, L.S., Aghadasi, M.: Proposing a model for purchasing system transformation. In: Proceedings 16th Conference EurOMA, Glasgow, Scotland (2006)

9. Van Weele, A.J.: Purchasing and Supply Chain Management. Thompson Learning, London (2005)

10. Leenders, M., Fearon, H.E., Flynn, A.E., Johnson, P.F.: Purchasing and Supply Management. McGraw Hill/Irwin, New York (2002)

11. Errasti, A.: Gestión de compras en la empresa, ediciones Pirámide, Grupo Anaya, Madrid, p. 280 (2012)

12. Meixell, M., Gargeya, V.: Global Supply Chain Design: A literature Review and A Critique. Transportation Research Part E 41, 531 (2005)

13. Kinkel, S., Maloca, S.: Drivers and antecedents of manufacturing offshoring and backshoring. A German Perspective. Journal of Purchasing \& Suppply Management 15, 154-165 (2009)

14. Vereecke, A., Van Dierdonck, R.: The strategic role of the plant: testing Ferdow's model. International Journal of Operations and Production Management 22, 492-514 (2002)

15. Shi, Y.: Internationalization and evolution of manufacturing systems: classic process models, new industrial issues, and academic challenges. Integrated, Manufacturing Systems 14, 385-396 (2003)

16. Azevedo, A., Almeida, A.: Factory Templates for Digital Factories Framework. Robotics and Computer-Integrated Manufacturing 27, 755-771 (2011)

17. Gill, J., Johnson, P.: Research Methods for Managers. Paul Chapman Publishing, London (1991)

18. Mingers, J., Brocklesby, J.: Multimethodology: towards a framework to mixture methodologies. Omega: International Journal of Management Science 25(5), 489-507 (1997)

19. Karlsson, C.: Researching Operations Management. Routledge, UK (2009)

20. Meredith, J.: Theory building through conceptual methods. International Journal of Operations and Production Management 13(5), 3-11 (1993) 
21. Westbrook, R.: Action Research: a new paradigm for research in production and operations management. International Journal of Operations and Production Management 15(12), 6-20 (1995)

22. Voss, C., Tsikriktsis, N., Frohlich, M.: Case Research in operations management. International Journal of Operations and Production Management 22(2), 195-219 (2002)

23. Yin, R.K.: Case Study Research: Design and methods, 4th edn. SAGE Publications, Inc. (2009)

24. Erkes, K., Clark, M.: Public Domain Report Number 1, Rapport pour le domaine publique du projet Européen ESPRIT 418, Avril (1987)

25. Roboam, M., Doumeingts, G., Dittman, K., Clark, M.: Public Domain Report Number 2. Rapport pour le domaine publique du projet Européen ESPRIT 418 (September 1987)

26. Luzarraga, J.M.: Mondragon Multi-Location Strategy- Innovating a Human Centred Globalisation Mondragon University, Oñati, Spain (2008)

27. Errasti, A.: International Manufacturing Networks: Global Operations Design and Management. Servicio Central de Publicaciones del Gobierno Vasco, San Sebastian, Spain (2011)

28. Mediavilla, M., Errasti, A.: Framework for assessing the current strategic plant role and deploying a roadmap for its upgrading. An empirical study within a global operations network, APMS, Cuomo, Italy (2010)

29. Abele, E., Meyer, T., Näher, U., Strube, G., Sykes, R.: Global production: a handbook for strategy and implementation. Springer, Heidelberg (2008)

30. Trent, R.J., Monczka, R.M.: Pursuing competitive advantage through integrated global sourcing. Academy of Management Executive 16(2), 66-80 (2002)

31. Gelderman, C.J., Semeijn, J.: Managing the global supply base through purchasing portfolio management. Journal of Purchasing and Supply Management 12, 209-217 (2006)

32. Ferdows, K.: Making the most of foreign factories. Harvard Business Review, 73-88 (March-April 1997)

33. Kurtila, P., Shaw, M., Helo, P.: Model Factory concept-Enabler for quick manufacturing capacity ramp up (2010)

34. Monczka, R.M., Handfield, R.B., Guinipero, L.C., Patterson, J.L.: Purchasing and Supply Chain Management, 4th edn. South-Western Cengage Learning, USA (2009)

35. Errasti, A., Oyarbide, A., Santos, J.: Construction Process Reengineering. In: Proceedings of Faim, Bilbao, Spain (2005)

36. Errasti, A., Egaña, M.M.: Internacionalización de operaciones: estado del arte, Cluster de movilidad, logística y transporte, San Sebastian (2009)

37. Taylor, D., Brunt, D.: Manufacturing operations and supply chain management: The lean approach. Cengage learning, United Kingdom (2010)

38. Wikner, J., Rudberg, M.: Integrating production and engineering perspectives on the customer order decoupling point. International Journal of Operations and Production Management 25(7), 623-664 (2005)

39. Trent, R.J., Monczka, R.M.: Understanding integrated global sourcing. International Journal of Physical Distribution and Logistics Management 33(7), 607-629 (2003)

40. Kasanen, E., Lukka, K., Siitonen, A.: The constructive approach in management accounting research. Journal of Management Accounting Research 5, 243-264 (1993) 